\title{
Pengaruh Risk Profile, Earnings, dan Capital terhadap Profitabilitas Perbankan di BEI Tahun 2016-2018
}

\author{
Gusti Agung Putu Dian Yunita1 \\ Fakultas Ekonomi dan Bisnis \\ Universitas Udayana, Indonesia
}

\author{
Ni Gusti Putu Wirawati² \\ Fakultas Ekonomi dan Bisnis \\ Universitas Udayana, Indonesia
}

\begin{abstract}
Surel : dian29yunita@gmail.com
ABSTRAK

Bank sebagai financial intermediary merupakan lembaga keuangan yang penting bagi aktivitas perekonomian di suatu negara. Penting bagi perbankan untuk memiliki kinerja keuangan yang baik. Kinerja bank tercermin dalam laporan keuangan masing-masing bank atau laporan perbankan yang telah dipublikasikan, dengan memperhatikan profitabilitas bank tersebut. Penelitian ini bertujuan untuk mengetahui pengaruh loan to deposit ratio (LDR), non performing loan (NPL), beban operasional terhadap pendapatan operasional (BOPO), net interest margin (NIM), dan capital adequacy ratio (CAR) terhadap profitabilitas. Penelitian ini dilakukan pada Bank Umum Swasta Nasional Devisa yang terdaftar di Bursa Efek Indonesia (BEI) tahun 2016-2018. Sampel yang diambil sebanyak 22 perusahaan dengan jumlah sampel penelitian sebanyak 66 amatan, melalui metode non probability dengan teknik purposive sampling. Teknik analisis data yang digunakan adalah regresi linear berganda. Hasil penelitian ini menunjukkan bahwa LDR dan NPL tidak berpengaruh terhadap profitabilitas. Sedangkan BOPO, NIM, dan CAR berpengaruh signifikan terhadap profitabilitas.
\end{abstract}

Kata Kunci: LDR; NPL; BOPO; NIM; CAR.

The Effects of Risk Profile, Earnings, and Capital on Profitability of Banks in the Indonesia Stock Exchange 2016 $-2018$

\begin{abstract}
Banks as financial intermediaries are important financial institutions for economic activities in a country. It is important for banks to have good financial performance. Bank performance is reflected in each banks financial statements or published banking reports, taking into account the banks profitability. The purpose of this study was to determine the effect of loan to deposit ratio (LDR), non performing loan (NPL), operational efficiency ratio, net interest margin (NIM), and capital adequacy ratio (CAR). This research was conducted at the Foreign Exchange National Private Commercial Bank listed on the Indonesia Stock Exchange in 2016-2018. Sample taken were 22 companies with a total of 66 research sample, through non-probability methods with purposive sampling technique. The analysis technique used in this research is multiple linear regression. The results shows that LDR and NPL did not affect on profitability. While operational efficiency ratio, NIM, and CAR significant affect on the profitability.
\end{abstract}

Keywords: $\quad$ LDR; NPL; Operational Efficiency Ratio; NIM; CAR.

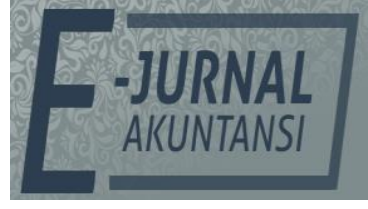

e-ISSN 2302-8556

Vol. 30 No. 8

Denpasar, Agustus 2020

Hal. 2102-2114

10.24843/EJA.2020.v30.10

PENGUTIPAN:

Yunita, G. A. P. D. \&

Wirawati, N. G. P. (2020).

Pengaruh Risk Profile,

Earnings, dan Capital terhadap Profitabilitas

Perbankan di BEI Tahun

2016-2018. E-Jurnal Akuntansi,

30(8), 2102-2114

RIWAYAT ARTIKEL:

Artikel Masuk:

17 April 2020

Artikel Diterima:

13 Juli 2020

Artikel dapat diakses : https://ojs.unud.ac.id/index.php/Akuntansi/index 


\section{PENDAHULUAN}

Bank sebagai financial intermediary memiliki fungsi dalam kegiatan menghimpun dana dari masyarakat dalam bentuk simpanan dan menyalurkan kembali kepada masyarakat dalam bentuk kredit untuk meningkatkan taraf hidup rakyat banyak (Kasmir, 2014:24). Bank sebagai lembaga intermediasi harus memiliki kinerja keuangan yang baik, tercermin dalam laporan keuangan masing-masing bank, dengan memperhatikan profitabilitas bank tersebut. Profitabilitas mencerminkan kemampuan perusahaan dalam memperoleh laba atau ukuran efektivitas pengelolaan manajemen perusahaan agar perusahaan mengetahui berapa laba yang diperoleh dalam suatu periode tertentu (Wiagustini, 2014:86). Profitabilitas dalam penelitian ini menggunakan Return On Assets (ROA) dalam pengukurannya.

Krisis ekonomi yang pernah di alami Indonesia memberikan gambaran pentingnya kesehatan dan sistem ketahanan bank, sehingga menjadi suatu hal yang penting untuk diperhatikan OJK sebagai badan pengawasan bank. Sebagai bentuk perhatian kesehatan perbankan, OJK mengeluarkan kebijakan penilaian tingkat kesehatan bank yang diatur pada Peraturan Otoritas Jasa Keuangan nomor 4/POJK.03/2016 mengenai tingkat kesehatan bank dengan menggunakan pendekatan risiko (risk-based banking rating) yang terdiri dari empat faktor, yakni Risk profile, Good Corporate Governance, Earnings dan Capital.

Perbankan dalam menjalankan kegiatan operasional tentu saja tidak lepas dari berbagai macam risiko yang disebut dengan risk profile. Peneliti menggunakan beberapa risiko yang cenderung mempengaruhi terjadinya risiko terhadap profitabilitas bank, yaitu risiko kredit, risiko likuiditas, dan risiko operasional. Risiko likuiditas adalah risiko yang dihadapi oleh perbankan dalam memenuhi permintaan kredit dan semua penarikan dana oleh nasabah dalam suatu waktu. Loan to Deposit Ratio (LDR) digunakan untuk mengukur risiko likuiditas dalam penelitian ini. Penyaluran kredit merupakan aktivitas utama suatu bank, dalam menghasilkan keuntungan yang bersumber dari pendapatan bunga. Semakin besarnya jumlah kredit yang disalurkan, maka dapat meningkatkan profitabilitas, begitu pula sebaliknya.

Selain menjadi keuntungan dan pendapatan bank, kegiatan penyaluran kredit dapat menjadi penyebab suatu bank mengalami risiko kredit. Semakin banyak kredit yang disalurkan, maka semakin besar risiko kredit yang dihadapi oleh bank. Risiko tersebut berupa tidak lancarnya pembayaran kredit atau kredit bermasalah yang dapat diukur dengan rasio Non Performing Loan (NPL). Peraturan Otoritas Jasa Keuangan nomor 15/POJK.03/2017 menyebutkan angka indikatif untuk rasio NPL yaitu maksimum $5 \%$ dari total kredit yang disalurkan. Semakin rendah persentase NPL, maka bank tersebut akan mengalami keuntungan, tetapi jika justru sebaliknya persentase NPL yang semakin tinggi, maka bank tersebut akan mengalami kerugian, yang berpengaruh terhadap profitabilitas. Menghadapi berbagai persaingan dan tuntutan dari para nasabah, pengelolaan bank secara efisien merupakan salah satu faktor penting bagi bank untuk menjaga kelangsungan operasionalnya dalam jangka waktu lama (Prasetyo \& Darmayanti, 2018). Risiko operasional dalam penelitian ini diukur dengan rasio beban operasional terhadap pendapatan operasional (BOPO). Rasio $\mathrm{BOPO}$ digunakan untuk mengukur tingkat efisiensi dan kemampuan bank 
dalam melakukan kegiatan operasional. Semakin rendah BOPO berarti semakin efisien bank tersebut dalam mengendalikan biaya operasionalnya, sehingga pendapatan yang didapat meningkat dan berdampak pada peningkatan profitabilitas.

Earning merupakan salah satu dasar penilaian kinerja manajemen dalam mengelola kegiatan operasional bank. Earnings dapat diukur dengan rasio Net Interest Margin (NIM). NIM menunjukkan kemampuan bank dalam menghasilkan pendapatan dari bunga dengan melihat kinerja bank dalam menyalurkan kredit (Nugraha, 2018). Semakin tinggi rasio NIM maka semakin baik juga kinerja yang dicapai oleh suatu bank, sehingga akan meningkatkan profitabilitas. Pengelolaan risiko yang baik dan kemampuan bank dalam menghasilkan pendapatan bunga saja tidak cukup menggambarkan kesehatan bank yang baik apabila kemampuan permodalan bank tidak diawasi. Modal merupakan faktor penentu utama dalam kapasitas pinjaman, karena modal tersebut bertujuan untuk menciptakan keseimbangan dan menyerap kerugian, serta dapat menjaga kepercayaan nasabah. Dalam penelitian ini digunakan Capital Adequecy Ratio (CAR) mewakili aspek permodalan (Capital) dalam penilaian tingkat kesehatan bank. Berdasarkan peraturan OJK nomor 15/POJK.03/2017 permodalan yang disyaratkan untuk mendapatkan penialain bank yang sehat adalah $8 \%$. Dengan begitu, diharapkan pemenuhan modal inti minimum dapat terpenuhi. Jika nilai CAR tinggi maka bank tersebut mampu membiayai kegiatan operasional dan memberikan kontribusi yang cukup besar bagi profitabilitas (Andika, 2017). Sampel dalam penelitian ini yaitu Bank umum swasta nasional (BUSN) devisa yang dimana sebagian besar modalnya dimiliki oleh pihak swasta non asing dan dapat melakukan transaksi ke luar negeri atau yang berhubungan dengan mata uang asing secara keseluruhan. Dalam kegiatannya BUSN devisa tidak melibatkan pemerintah seperti bank persero, sehingga persaingan di antara bank BUSN devisa sangat ketat dalam mencapai profitabilitasnya. Berdasarkan uraian latar belakang di atas, adapun rumusan masalah dalam penelitian ini adalah: apakah LDR, NPL, BOPO, NIM, dan CAR berpengaruh terhadap profitabilitas perbankan yang terdaftar di BEI tahun 20162018.

Penelitian ini bertujuan untuk mengetahaui pengaruh LDR, NPL, BOPO, NIM, dan CAR terhadap profitabilitas. Penelitian ini juga diharapkan mampu memberikan manfaat teoritis maupun praktis. Secara teoritis, penelitian ini dapat memberikan kontribusi secara akademisi, dan secara praktis dapat memberikan referensi bagi pihak-pihak yang berkepentingan.

Penelitian ini menggunakan Signaling Theory mengindikasikan bahwa perusahaan akan berusaha untuk menunjukan sinyal berupa informasi positif kepada nasabah bank potensial melalui pengungkapan dalam laporan keuangan. Adanya penilaian tingkat kesehatan bank yang diperoleh dari pemilik informasi akan memberi sinyal untuk pengambilan keputusan nasabah bank selaku penerima informasi agar mempercayai dan menitipkan dana mereka pada pihak bank.

LDR merupakan rasio antara seluruh jumlah kredit yang disalurkan terhadap dana pihak ketiga (Pinasti \& Mustikawati, 2018). Semakin tinggi rasio LDR menunjukan semakin baik suatu bank dalam menyalurkan dana pihak 
ketiga yang dimiliknya ke dalam bentuk kredit yang disalurkan, hal tersebut akan meningkatkan pendapatan bunga yang diterima bank, sehingga akan berpengaruh terhadap peningkatan profitabilitas.

Besarnya LDR dianggap memenuhi syarat ketentuan apabila besarnya LDR antara $78 \%$ hingga $100 \%$. LDR yang dibawah ketentuan dapat dikatakan bahwa bank memelihara likuid yang berlebihan dan ini akan menimbulkan tekanan terhadap pendapatan bank berupa tingginya biaya pemeliharaan kas yang menganggur. Negara dan Natalia (2016) dalam penelitiannya menyatakan kredit yang disalurkan memiliki pengaruh signifikan terhadap profitabilitas. Hasil penelitian lainnya oleh Gizaw et al. (2015) menemukan bahwa LDR berpengaruh terhadap ROA.

$\mathrm{H}_{1}$ : LDR berpengaruh terhadap profitabilitas perbankan yang terdaftar di BEI pada tahun 2016-2018.

NPL merupakan suatu rasio akibat kegagalan atau ketidakmampuan nasabah dalam mengembalikan jumlah pinjaman yang diterima beserta bunganya, sesuai jangka waktu yang telah ditentukan (Dewi \& Ariyanto, 2018). Peraturan Otoritas Jasa Keuangan nomor 15/POJK.03/2017 angka indikatif untuk rasio kredit bermasalah yaitu maksimum sebesar $5 \%$ dari seluruh outstanding pinjaman yang harus dicapai perbankan nasional.

Kondisi NPL yang tinggi akan memperbesar biaya baik biaya pencadangan aktiva produktif maupun biaya yang lain, sehingga berpotensi untuk menimbulkan kerugian pada bank, atau dengan kata lain NPL menurunkan profitabilitas (ROA) bank (Wulandari, 2018). Penelitian yang dilakukan oleh Safariah (2015) menghasilkan NPL berpengaruh terhadap pertumbuhan laba. Dari uraian tersebut, dapat dirumuskan hipotesis penelitian sebagai berikut :

$\mathrm{H}_{2}$ : NPL berpengaruh terhadap profitabilitas perbankan yang terdaftar di BEI pada tahun 2016-2018.

BOPO adalah rasio perbandingan beban operasioanal terhadap pendapatan operasional. Semakin kecil rasio BOPO berarti semakin efisien suatu bank menjalankan aktivitas usahanya, sehingga dapat meningkatkan profitabilitas bank. Begitupun sebaliknya nilai BOPO yang tinggi menunjukkan semakin tidak efisien suatu bank menjalankan aktivitasnya, sehingga dapat menurukan profitabilitas bank (Safariah, 2015). Hasil penelitian yang dilakukan oleh (Syafi'i, 2016) menyatakan BOPO berpengaruh signifikan terhadap profitabilitas.

$\mathrm{H}_{3}$ : BOPO operasional berpengaruh terhadap profitabilitas perbankan yang terdaftar di BEI pada tahun 2016-2018.

NIM merupakan rasio yang menunjukan kemampuan manajemen bank dalam mengelola aktiva produktifnya untuk menghasilkan pendapatan bunga bersih. Aktiva produktif adalah penyediaan dana bank untuk memperoleh pendapatan dalam bentuk pinjaman. Meningkatnya pendapatan bunga dapat memberikan kontribusi laba kepada bank. Sehingga dapat disimpulkan bahwa semakin besar perubahan NIM suatu bank, maka semakin besar pula profitabilitas bank tersebut, yang berarti kinerja keuangan tersebut semakin meningkat. Penelitian yang dilakukan oleh Wulandari (2018) mengatakan bahwa 
NIM memiliki pengaruh signifikan terhadap ROA sehingga diperoleh hipotesis sebagai berikut.

$\mathrm{H}_{4}$ : NIM berpengaruh terhadap profitabilitas perbankan yang terdaftar di BEI pada tahun 2016-2018.

CAR merupakan rasio permodalan yang menunjukkan kemampuan bank dalam menyediakan dana untuk keperluan pengembangan usaha dan menampung risiko kerugian dana yang diakibatkan oleh kegiatan operasional bank. Semakin tinggi rasio CAR maka menunjukkan semakin kuat kemampuan bank untuk menanggung risiko dari setiap kredit atau aktiva produktif yang berisiko, dan bank tersebut mampu membiayai operasinya sehingga akan memberikan kontribusi yang cukup besar bagi profitabilitas (Kuncoro \& Suhardjono, 2011).

Hasil penelitian yang dilakukan oleh (Darmawan \& Suartana, 2018) yang menunjukkan bahwa rasio kecukupan modal berpengaruh signifikan terhadap profitabilitas. Dari uraian tersebut, maka dapat dirumuskan hipotesis penelitian sebagai berikut.

$\mathrm{H}_{5}$ : CAR berpengaruh terhadap profitabilitas perbankan yang terdaftar di BEI pada tahun 2016-2018.

\section{METODE PENELITIAN}

Penelitian ini dilakukan pada Bursa Efek Indonesia (BEI) yang menyediakan informasi laporan keuangan perusahaan yang dapat diperoleh dengan mengakses situs resmi Bursa Efek Indonesia yaitu www.idx.co.id. Lokasi penelitian ini dipilih karena populasi dalam penelitian ini adalah seluruh Bank Umum Swasta Nasional (BUSN) Devisa yang terdaftar dan mempublikasikan laporan keuangannya di Bursa Efek Indonesia (BEI).

Variabel bebas yang digunakan dalam penelitian ini adalah, Non Performing Loan $\left(\mathrm{X}_{1}\right)$, Loan to Deposit Ratio $\left(\mathrm{X}_{2}\right)$, BOPO $\left(\mathrm{X}_{3}\right)$, Net Interest Margin $\left(\mathrm{X}_{4}\right)$, Capital Adequacy Ratio $\left(\mathrm{X}_{5}\right)$. Variabel terikat dalam penelitian ini adalah profitabilitas (Y). LDR merupakan perbandingan total kredit terhadap Dana Pihak Ketiga (DPK) yang dihimpun oleh bank (Riyadi, 2015:199). NPL merupakan rasio yang dipergunakan untuk mengukur kemampuan bank dalam mengukur risiko kegagalan pengembalian kredit oleh debitur. BOPO adalah rasio yang digunakan untuk mengukur tingkat efisiensi dan kemampuan bank dalam melakukan kegiatan operasinya. NIM merupakan rasio yang menunjukan kemampuan manajemen bank dalam mengelola aktiva produktifitasnya untuk menghasilkan pendapatan bunga bersih. CAR merupakan rasio permodalan yang menunjukan kemampuan bank dalam menyediakan dana untuk keperluan pengembangan usaha dan menampung risiko kerugian yang diakibatkan oleh kegiatan operasional bank. ROA digunakan untuk mengukur efektivitas perusahaan dalam memperoleh penghasilan dalam kegiatan operasi perusahaan dengan memanfaatkan aktiva yang dimiliki perusahaan.

Populasi dalam penelitian ini adalah seluruh Bank Umum Swasta Nasional (BUSN) Devisa yang terdaftar di BEI dalam kurun waktu 2016-2018 dan masih aktif beroperasi secara normal. Sampel diambil dari populasi tersebut dengan pendekatan non probabilitas menggunakan teknik purposive sampling. Bank umum milik swasta nasional merupakan bank yang seluruh atau sebagian 
besar sahamnya dimiliki oleh pihak swasta, dalam kegiatannya BUSN devisa tidak melibatkan pemerintah seperti bank persero, sehingga persaingan di antara bank BUSN devisa sangat ketat dalam mencapai profitabilitasnya. Kriteria dalam penelitian ini adalah bank umum swasta nasional devisa yang terdaftar di Bursa Efek Indonesia tahun 2016-2018, menerbitkan laporan tahunan berturut-turut selama periode pengamatan, serta tidak mengalami kerugian selama periode penelitian.

Teknik analisis data yang digunakan dalam penelitian ini adalah analisis regresi linier berganda yang digunakan untuk menguji pengaruh variabel independent secara bersama-sama (simultan) terhadap variabel dependent. Berdasarkan pembahasan pembahasan sebelumnya maka bentuk persamaan regresi berganda penelitian ini menggunakan model sebagai berikut.

$Y=\alpha+\beta_{1} X_{1}+\beta_{2} X_{2}+\beta_{3} X_{3}+\beta_{4} X_{4}+\beta_{5} X_{5}+\varepsilon$

$$
\begin{aligned}
& \text { Keterangan: } \\
& Y=\text { ROA (Profitabilitas) } \\
& X_{1}=\text { LDR } \\
& X_{2}=\text { NPL } \\
& X_{3}=\text { BOPO } \\
& X_{4}=\text { NIM } \\
& X_{5}=\text { CAR } \\
& e=\text { Error } \\
& \alpha=\text { Konstanta } \\
& \beta=\text { Koefisien Regresi }
\end{aligned}
$$

\section{HASIL DAN PEMBAHASAN}

Statistik deskriptif disajikan untuk memberikan informasi mengenai karakteristik variabel-variabel penelitian, yaitu jumlah sampel, nilai maksimum, nilai minimum, nilai rata-rata dan standar deviasi. Hasil statistik deskriptif penelitian yaitu variabel Loan to Deposit Ratio (LDR) memiliki nilai minimum sebesar 50,61 dan maksimum sebesar 145,26. Mean dari LDR adalah 85,61 Standar deviasi pada variabel ini lebih kecil daripada nilai mean sehingga variabel ini memiliki fluktuasi kecil pada perusahaan yang diteliti. Variabel Non Performing Loan (NPL) memiliki nilai minimum sebesar 0,03 dan maksimum sebesar 15. Mean dari NPL adalah 2,98. Standar deviasi pada variabel ini lebih kecil daripada nilai mean yaitu sebesar 2,28 sehingga variabel ini memiliki fluktuasi kecil pada perusahaan yang diteliti.

Variabel Beban Operasional Terhadap Pendapatan Operasional (BOPO) memiliki nilai minimum sebesar 58,20 dan maksimum sebesar 235,20. Mean dari BOPO adalah 86,89 dengan nilai standar deviasi sebesar 21,12. Standar deviasi pada variabel ini lebih kecil daripada nilai mean sehingga variabel ini memiliki fluktuasi kecil pada perusahaan yang diteliti. Variabel Net Interest Margin (NIM) memiliki nilai minimum sebesar 2,83 dan maksimum sebesar 12,00. Mean dari NIM adalah 5,47 dengan nilai standar deviasi sebesar 1,89 persen. Standar deviasi pada variabel ini lebih kecil daripada nilai mean sehingga variabel ini memiliki fluktuasi kecil pada perusahaan yang diteliti. Variabel Capital Adequacy Ratio (CAR) memiliki nilai minimum sebesar 10,52 dan maksimum sebesar 42,64. 
Mean dari CAR adalah 22,57 dengan nilai standar deviasi sebesar 6,45. Standar deviasi pada variabel ini lebih kecil daripada nilai mean sehingga variabel ini memiliki fluktuasi kecil pada perusahaan yang diteliti.

Variabel Return On Asset (ROA) memiliki nilai minimum sebesar 0,09 dan maksimum sebesar 11,15. Mean dari ROA adalah 1,82 dengan nilai standar deviasi sebesar 1,53. Standar deviasi pada variabel ini lebih kecil daripada nilai mean sehingga variabel ini memiliki fluktuasi kecil pada perusahaan yang diteliti.

Tabel 1. Hasil Uji Statistik Deskriptif

\begin{tabular}{lccccc}
\hline & $\mathrm{N}$ & Minimum & Maximum & Mean & Std.Deviation \\
\hline ROA & 66 & 0,09 & 11,15 & 1,82 & 1,53 \\
CAR & 66 & 10,52 & 42,64 & 22,57 & 6,45 \\
NPL & 66 & 0,03 & 15,82 & 2,98 & 2,28 \\
NIM & 66 & 2,83 & 12,00 & 5,47 & 1,89 \\
BOPO & 66 & 58,20 & 235,20 & 86,89 & 21,12 \\
LDR & 66 & 50,61 & 145,26 & 85,61 & 15,59 \\
Valid N (listwise) & 66 & & & & \\
\hline
\end{tabular}

Sumber : Data Penelitian, 2019

Uji normalitas bertujuan untuk mengetahui apakah residual dari model regresi yang dibuat berdistribusi normal atau tidak. Untuk menguji apakah data yang digunakan normal atau tidak dapat dilakukan dengan menggunakan uji Kolmogorov Smirnov. Berdasarkan Tabel 2, dapat dilihat bahwa nilai Kolmogorov Smirnov (K-S) sebesar 0,08, sedangkan nilai Asymp. Sig. (2-tailed) sebesar 0,20. Hasil tersebut mengindikasikan bahwa model persamaan regresi tersebut berdistribusi normal karena nilai Asymp. Sig. (2-tailed) 0,20 lebih besar dari nilai alpha 0,05 .

Tabel 2. Hasil Uji Normalitas

\begin{tabular}{lrr}
\hline & One-Sample Kolmogorov-Smirnov Test & \\
\hline & & Unstandardized Residual \\
\hline $\mathrm{N}$ & & 66 \\
Normal Parametersa,b & Mean & 0,00 \\
& Std. Deviation & 0,21 \\
Most Extreme Differences & Absolute & 0,08 \\
& Positive & 0,06 \\
& Negative & $-0,08$ \\
Test Statistic & & 0,08 \\
Asymp. Sig. (2-tailed) & & $0,20^{c, \mathrm{~d}}$ \\
\hline
\end{tabular}

Sumber : Data Penelitian, 2019

Berdasarkan Tabel 3, dapat dilihat bahwa Nilai DW 1,82, nilai ini bila dibandingkan dengan nilai tabel signifikansi 5\%, jumlah sampel 66 (n) dan jumlah variabel independen $(\mathrm{K}=5)$ maka diperoleh nilai du 1,7675. Nilai DW 1,82 lebih besar dari batas atas (du) yakni 1,7675 dan kurang dari (4-du) 4-1,7675= 2,2325, maka dapat disimpulkan bahwa tidak terdapat autokorelasi.

Tabel 3. Hasil Uji Autokorelasi

\begin{tabular}{cccccc}
\hline Model & $\mathrm{R}$ & $\mathrm{R}$ Square & $\begin{array}{c}\text { Adjusted } \mathrm{R} \\
\text { Square }\end{array}$ & $\begin{array}{c}\text { Std. Error of the } \\
\text { Estimate }\end{array}$ & $\begin{array}{c}\text { Durbin- } \\
\text { Watson }\end{array}$ \\
\hline 1 & $0,64^{\mathrm{a}}$ & 0,41 & 0,36 & 1,22 & 1,82 \\
\hline
\end{tabular}

Sumber : Data Penelitian, 2019 
Pada Tabel 4, dapat dilihat bahwa nilai signifikansi dari variabel ROA sebesar 0,574, CAR sebesar 0,131, NPL sebesar 0,79, NIM sebesar 0,310, BOPO sebesar 0,938 , LDR sebesar 0,959 . Nilai tersebut lebih besar dari 0,05 yang berarti tidak terdapat pengaruh antara variabel bebas terhadap absolute residual. Dengan demikian, model yang dibuat tidak mengandung gejala heteroskedastisitas.

\section{Tabel 4. Hasil Uji Heteroskedastisitas}

\begin{tabular}{lccccc}
\hline & \multicolumn{2}{c}{$\begin{array}{c}\text { Unstandardized } \\
\text { Coefficients }\end{array}$} & $\begin{array}{c}\text { Standardized } \\
\text { Coefficients }\end{array}$ & & \\
\cline { 2 - 3 } & $\mathrm{B}$ & Std. Error & Beta & $\mathrm{T}$ & Sig. \\
\hline ROA &,- 525 &, 931 & &,- 565 &, 574 \\
CAR &, 025 &, 016 &, 192 & 1,530 &, 131 \\
NPL &, 134 &, 075 &, 129 & 1,786 &, 079 \\
NIM &, 058 &, 056 &, 129 & 1,024 &, 310 \\
BOPO &, 001 &, 008 & 0,16 &, 078 &, 938 \\
LDR &, 000 &, 007 &,- 006 &,- 051 &, 959 \\
\hline
\end{tabular}

Sumber : Data Penelitian, 2019

Pada Tabel 5, dapat dilihat nilai tolerance dan nilai Variance Inflaction Factor (VIF) dari hasil uji multikolinieritas menunjukan tidak ada variabel bebas yang memiliki nilai tolerance kurang dari 0,10 (10\%). Begitu juga dengan nilai variance inflaction factor (VIF) yang menunjukan tidak ada satu variabel bebas yang memiliki nilai VIF lebih dari 10. Maka dapat disimpulkan bahwa tidak ada multikolinieritas antar variabel bebas dalam model regresi.

Tabel 5. Hasil Uji Multikolinieritas

\begin{tabular}{lllr}
\hline & \multirow{2}{*}{ Model } & \multicolumn{2}{c}{ Collinearity Statistics } \\
\cline { 3 - 4 } & & Tolerance & VIF \\
\hline 1 & CAR & 0,88 & 1,14 \\
& NPL & 0,34 & 2,97 \\
& NIM & 0,87 & 1,15 \\
& BOPO & 0,32 & 3,13 \\
& LDR & 0,93 & 1,07 \\
\hline
\end{tabular}

Sumber : Data Penelitian, 2019

Penelitian ini menggunakan model regresi linear berganda yang diolah dengan bantuan aplikasi SPPS versi 23. Analisis hasil regresi ini dilakukan untuk mengetahui besarnya pengaruh rasio CAR, NPL, NIM, BOPO, dan LDR terhadap profitabilitas bank umum swasta nasional devisa tahun 2016 sampai dengan tahun 2018. Hasil analisis regresi linier berganda berdasarkan Tabel 6, maka dapat dibuat persamaan regresi sebagai berikut :

$$
Y=-5,195+0,014 X_{1}+0,088 X_{2}+0,028 X_{3}+0,275 X_{4}+0,069 X_{5}+\varepsilon
$$

Uji koefisien determinasi digunakan untuk menguji goodness-fit dari model regresi. Perhitungan R2 yang digunakan adalah nilai adjusted $\mathrm{R}^{2}$, karena ini merupakan salah satu indikator untuk mengetahui pengaruh penambahan satu variabel independen ke dalam model persamaan regresi (Gozali, 2016:95). Tabel 6, menunjukan bahwa besarnya nilai adjusted $\mathrm{R}^{2}$ sebesar 0,365 yang artinya variabilitas variabel dependen yang dapat dijelaskan oleh variabilitas variabel independen sebesar $36,5 \%$, sedangkan sisanya $(100 \%-36,5 \%=63,5 \%)$ dijelaskan oleh variabel lain diluar model. Berdasarkan Tabel 6, nilai signifikansi F menunjukan nilai 0,000. Nilai ini lebih kecil dari pada taraf signifikansi 0,05 yang 
artinya secara bersama-sama terdapat pengaruh variabel independen LDR, NPL, CAR, NIM, BOPO terhadap profitabilitas. Sehingga dapat disimpulkan model ini layak diteliti dan dapat dilanjutkan dengan pembuktian hipotesis.

Tabel 6. Hasil Uji Regresi Linear Berganda

\begin{tabular}{|c|c|c|c|c|c|c|}
\hline \multicolumn{2}{|c|}{ Model } & \multicolumn{2}{|c|}{$\begin{array}{l}\text { Unstandardized } \\
\text { Coefficients }\end{array}$} & \multirow{2}{*}{$\begin{array}{c}\text { Standardized } \\
\text { Coefficients } \\
\text { Beta }\end{array}$} & \multirow[b]{2}{*}{$\mathrm{t}$} & \multirow[b]{2}{*}{ Sig. } \\
\hline & & B & Std. Error & & & \\
\hline \multirow[t]{6}{*}{1} & (Constant) & $-5,195$ & 1,421 & & $-3,656$ & 001 \\
\hline & CAR & ,069 & ,025 & 289 & 2,745 & ,008 \\
\hline & NPL & 088 & ,115 & 130 & ,764 & 448 \\
\hline & NIM & 275 & ,086 & 339 & 3,191 & ,002 \\
\hline & ВOРО & ,028 & ,013 & 390 & 2,228 & ,030 \\
\hline & LDR & ,014 & ,010 & 147 & 1,433 & 157 \\
\hline \multicolumn{7}{|c|}{$\begin{array}{l}\mathrm{R}=0,643 ; \mathrm{R}^{2}=0,414 ; \text { Adjusted } \mathrm{R}^{2}=0,365 ; \\
\text { F hitung }=8,463 \text { (sig. }=0,000 \text { ). }\end{array}$} \\
\hline
\end{tabular}

Hasil uji t masing-masing variabel, yaitu: nilai $\mathrm{t}$ untuk variabel LDR adalah 1,433 dengan signifikansi sebesar 0,157 dimana nilai signifikan ini lebih besar daripada 0,05 (0,157>0,05). Hal ini menunjukan bahwa variabel LDR tidak berpengaruh secara parsial terhadap profitabilitas, sehingga hipotesis pertama ditolak. Hasil penelitian ini sejalan dengan hasil penelitian Wulandari (2018) yang menyatakan LDR tidak berpengaruh terhadap profitabilitas yang diproksikan dengan ROA. Loan to Deposit Ratio menunjukkan seberapa jauh kemampuan bank dalam membayar kembali penarikan dana yang dilakukan deposan dengan mengandalkan kredit yang diberikan sebagai sumber likuiditasnya (Wulandari, 2018). Semakin rendahnya nilai LDR berarti menunjukkan bank likuid dengan kelebihan kapasitas dana yang siap disalurkan sebagai pinjaman atau kredit. Sebaliknya, semakin tinggi LDR menunjukkan bahwa suatu bank menyalurkan sebagian besar dananya atau relatif tidak likuid. Optimalnya LDR dalam kegiatan usaha bank, akan dapat menghasilkan keuntungan. Hasil yang tidak signifikan dapat disebabkan pendapatan bank umum swasta nasional devisa tidak hanya dari pendapatan bunga pinjaman yang diberikan kepada msasyarakat tetapi juga dihasilkan dari pendapatan bunga berbasis komisi. Perbankan sudah mulai berpindah dan fokus untuk mendapatkan pendapatan dari bunga ke fee based income, karena pada saat ini nasabah bank juga makin banyak yang membutuhkan kemudahan dalam bertransaksi. Produk-produk itulah yang menjadi tambahan sumber pendapatan berbasis komisi.

Nilai t untuk variabel NPL adalah 0,764 dengan signifikansi sebesar 0,448 dimana nilai signifikan ini lebih besar daripada $0,05(0,448>0,05)$. Hal ini menunjukan bahwa variabel NPL tidak berpengaruh secara parsial terhadap profitabilitas, sehingga hipotesis kedua ditolak. Hasil penelitian ini didukung oleh penelitian yang dilakukan oleh Lestari \& Suartana (2017), yang menyatakan NPL tidak berpengaruh terhadap profitabilitas. Koefisien regresi yang bernilai positif tidak signifikan menunjukkan hubungan yang menjelaskan bahwa besarnya risiko kredit yang diproksikan dengan non performing loan (NPL) akan tetap mampu meningkatkan profitabilitas bank. Hal ini dapat dikarenakan meningkatnya aktiva produktif, yaitu kredit yang dapat meningkatkan cadangan 
modal untuk menyalurkan kredit besar, yang berpengaruh terhadap profitabilitas.

Nilai $\mathrm{t}$ untuk variabel BOPO adalah 2,228 dengan signifikansi sebesar 0,030 dimana nilai signifikan ini lebih kecil daripada $0,05(0,030<0,05)$. Hal ini menunjukan bahwa variabel $\mathrm{BOPO}$ berpengaruh positif secara parsial terhadap profitabilitas, sehingga hipotesisi ketiga diterima. Beban operasional bank merupakan semua beban atau biaya yang dikeluarkan bank untuk membiayai kegiatan operasionalnya, seperti beban bunga, beban penghapusan aktiva produktif, beban estimimasi kerugian komitmen dan kontinjensi, dan beban operasional lainnya yang berhubungan dengan kegiatan operasional bank (Siamat, 2005:384). Beban bunga merupakan biaya yang harus dikeluarkan bank kepada nasabah pemilik simpanan sebagai balas jasa atas penempatan dananya di bank. Peningkatan pada bunga simpanan dapat memberikan sinyal positif terhadap nasabah untuk menyimpan dananya di bank, sehingga ketika bank kekurangan dana sementara pinjaman meningkat, bank mampu memenuhi permintaan dana yang dibutuhkan tersebut. Meningkatnya pinjaman, akan diimbangi dengan pendapatan bunga. Sehingga semakin tinggi pendapatan bunga bank, semakin tinggi pula profitabilitas bank tersebut.

Nilai t untuk variabel NIM adalah 3,191 dengan signifikansi sebesar 0,002 dimana nilai signifikan ini lebih kecil daripada $0,05(0,002<0,05)$. Hal ini menunjukan bahwa variabel NIM berpengaruh positif secara parsial terhadap profitabilitas. Hasil penelitian ini sesuai dengan hasil penelitian yang dilakukan oleh Wulandari (2018) yang menyatakan bahwa NIM berpengaruh signifikan terhadap profitabilitas. Hipotesis ke-empat diterima. NIM adalah selisih antara pendapatan bunga yang diterima dari pinjaman bank dan aktiva produktif lainnya pada periode waktu tertentu dikurangi dengan jumlah bunga yang dibayarkan kepada pemegang utang bank dibagi dengan jumlah rata-rata aktiva produktif dalam periode waktu yang sama. Aktiva produktif adalah penyediaan dana bank untuk memperoleh pendapatan dalam bentuk pinjaman, surat berharga, penempatan antar bank, dan bentuk lain dari penyediaan dana. Jika manajemen bank telah melakukan langkah kehati-hatian dalam menyalurkan kredit maka kualitas aktiva produktifnya dapat tetap terjaga. Dengan kualitas aktiva produktif yang baik dapat meningkatkan pendapatan bunga yang mengakibatkan laba sebelum pajak meningkat sehingga profitabilitas pun akan meningkat. Hal ini berarti saat NIM meningkat ROA pun akan mengalami peningkatan.

Nilai t variabel CAR adalah 2,745 dengan signifikansi sebesar 0,008 dimana nilai signifikan ini lebih kecil daripada 0,05 $(0,008<0,05)$. Hal ini menunjukan bahwa variabel CAR berpengaruh positif terhadap profitabilutas secara parsial. Dengan demikian, hipotesis kelima diterima. CAR yang berpengaruh positif terhadap profitabilitas mencerminkan meningkatnya CAR dapat meningkatkan profitabilitas, dan sebaliknya jika CAR menurun profitabilitas juga akan menurun. Hasil penelitian ini sejalan dengan hasil penelitian yang dilakukan oleh Darmawan \& Suartana (2018) yang menyatakan bahwa rasio kecukupan modal berpengaruh positif terhadap profitabilitas. Semakin tinggi CAR mengindikasikan bahwa bank telah mempunyai permodalan yang cukup karena naiknya CAR membuat bank lebih leluasa dalam pengembangan usahanya dan 
menampung risiko kerugian yang diakibatkan oleh kegiatan operasional bank. Hal ini, dapat mendorong pasar untuk memberikan sinyal positif yang menunjukan bahwa perbankan memiliki kinerja yang baik, yang mampu membiayai kebutuhannya sendiri dari permodalan yang dimilikinya. Sinyal positif yang diberikan meningkatkan kepercayaan masyarakat yang dapat berpengaruh terhadap peningkatan profitabilitas perbankan.

\section{SIMPULAN}

Berdasarkan hasil analisis dan pembahasan yang telah dilakukan, maka dapat disimpulkan bahwa variabel loan to deposit ratio dan variabel non performing loan tidak berpengaruh terhadap profitabilitas pada bank umum swasta nasional devisa yang terdaftar di Bursa Efek Indonesia (BEI) tahun 2016 sampai dengan tahun 2018. Berbeda halnya dengan variabel Beban operasional terhadap pendapatan operasional, net interest margin dan variabel capital adequacy ratio memiliki pengaruh signifikan terhadap profitabilitas pada bank umum swasta nasional devisa yang terdaftar di Bursa Efek Indonesia (BEI) tahun 2016 sampai dengan tahun 2018.

Berdasarkan hasil penelitian maka saran yang dapat diajukan adalah bagi industri perbankan untuk selalu memperhatikan kinerjanya yang sudah baik dan terus meningkatkannya dengan upaya seperti, mengelola asetnya dengan baik untuk meningkatkan profitabilitas, dan menjaga kesehatan bank, dengan memperhatikan faktor-faktor tersebut diharapkan dapat memperoleh kinerja keuangan yang stabil dan optimal. Bagi nasabah atau investor bank, penelitian ini diharapkan dapat menjadi acuan atau referensi dalam mengamati dan mencermati kinerja keuangan perbankan dalam membuat keputusan investasi. Bagi akademisi memberikan bukti empiris terkait faktor-faktor yang mempengaruhi profitabilitas. Penelitian ini diharapkan dapat menjadi referensi untuk penelitian selanjutnya, dengan menambahkan variabel-variabel lain yang mempengaruhi profitabilitas bank.

\section{REFERENSI}

Alexandri, M. B., \& Santoso, T. I. (2015). Non Performing Loan: Impact of Internal and External Factor (Evidence in Indonesia). International Journal of Humanities and Social Science Invention, 4(1), 87-91.

Ali, A., Sabir, D. H. M.,\& Taqi, M. (2014). Do non perorming loan affect bank performance? evidence from listed banks at Karachi stock exchange (KSE) of Pakistan. International Journal of Research in Social Sciences, 4(1), 363.

Andika, W. P. (2017). Determinan Profitabilitas Bank Umum Konvensional Dengan Risiko Kredit Sebagai Variabel Moderating. Universitas Jember.

Buchory, H. A. (2014). Analysis of The Effect of Capital, Credit Risk and Profitability to Implementation Banking Intermediation Function. International Journal of Business, Economics and Law. https://doi.org/10.1093/oxfordhb/9780199552238.003.0036

Cahyani, N. P. D. W., \& Putri, I. A. . A. D. (2018). Pengaruh Risk Profile, Good Corporate Governance, Earnings dan Capital pada Perubahan Harga Saham Bank. E-Jurnal Akuntansi. https:// doi.org/10.24843/eja.2018.v25.i02.p06

Darmawan, K., \& Suartana, I. W. (2018). Tingkat Kecukupan Modal, 
Pertumbuhan Kredit, dan Risiko Operasional Pada Profitabilitas Lembaga Perkreditan Desa. E-Jurnal Akuntansi. https:/ / doi.org/10.24843/eja.2018.v25.i02.p13

Derbali, A. (2014). The impact of banking startegies on the net interest margin: Empirical evidence from Tunisia. International Journal of Innovation and Applied Studies, 6(1), Pp, 97-109.

Dewi, N. P. I. P.,\& Ariyanto, D. (2018). Pengaruh Tingkat Efisiensi, Risiko Kredit, dan Tingkat Penyaluran Kredit pada Profitabilitas. E-Jurnal Akuntansi Universitas Udayana, 24(2), 1164-1189.

Ekpu, V., \& Paloni, A. (2016). Business lending and bank profitability in the UK. Studies in Economics and Finance. https://doi.org/10.1108/SEF-04-2015-0097

Ghozali, I. (2016). Aplikasi Analisis Multivariate dengan Program IBM SPSS 23. (Edisi 8). Semarang: Badan Penerbit Universitas Diponegoro.

Gizaw, M., Matewos, K., \& Sujata, S. (2015). The impact of credit risk on profitability performance of commercial banks in Ethiopia. African Journal of Business Management. https://doi.org/10.5897/ajbm2013.7171

Hantono. (2017). Effect of Capital Adequacy Ratio (CAR), Loan to Deposit Ratio (LDR) and Non Performing Loan (NPL) to Return on Assets (ROA) Listed in Banking in Indonesia Stock Exchange. International Journal of Education and Research.

Honora, R. (2014). Camel Influence on Return Stocks on National Private Individual Commercial Banks Listed on the Stock Exchange the Period 2012-2014 Terdaftar Pada Bank Umum Swasta Nasional Pada. 1-8.

Iloska, N. (2014). Determinants of Net Interest Margins - The Case of Macedonia. Journal of Applied Economics and Business, 2(2).

Kasmir. (2014). Analisis Laporan Keuangan, Edisi Satu, Cetakan Ketujuh. In Raja Grafindo Persada.

Kuncoro dan Suhardjono. (2011). Manajemen Perbankan (Teori dan Aplikasi), edisi kedua. In BPFE, Yogjakarta. https:// doi.org/351.077 Ind r

Lata, R. S. (2015). Non Performing Loan and Probability: The Case of State Owned Commercial Banks in Bangladesh. World Review of Bussines Research, 5(3), pp:1.

Lestari, I Gusti Agung Oka Sri Indah \& Suartana, I. W. (2017). Pengaruh Tingkat Efisiensi, Risiko Kredit, dan Tingkat Penyaluran Kredit pada Profitabilitas Lembaga Perkreditan Desa (LPD). E-Jurnal Akuntansi Unversitas Udayana. 19(2), 1661-1690.

Marinkovic, Srdan \& Radovic, O. (2014). Bank net interest margin related to risk, ownership and size: and exploratory study of the Serbian banking Industry. Journal of Economic Research-Ekonomska Istrazivanja, 27(1), pp:

Menicucci, E., \& Paolucci, G. (2016). The determinants of bank profitability: empirical evidence from European banking sector. Journal of Financial Reporting and Accounting. https://doi.org/10.1108/jfra-05-2015-0060

Negara, I. W. S., \& Natalia, N. K. D. (2016). Pengaruh Loan To Deposit Ratio Dan Capital Adequacy Ratio Terhadap Profitabilitas Bank Umum Konvensional Di Indonesia Tahun 2010 - 2014 Dengan Non Performing Loan. Jurnal Riset Akuntansi, 06(4), 71-78.

Nugraha, S. G. (2018). Penggunaan Metode Risk Based Bank Rating untuk 
Menganalisis Tingkat Kesehatan Bank (Studi pada Bank yang Terdaftar pada Bursa Efek Indonesia Tahun 2011-2015). Universitas Lampung.

Pinasti, W. F., \& Mustikawati, R. I. (2018). Pengaruh Car, Bopo, Npl, Nim Dan Ldr Terhadap Profitabilitas Bank Umum Periode 2011-2015. Nominal, Barometer Riset Akuntansi Dan Manajemen, 7(1). https:// doi.org/10.21831/nominal.v7i1.19365

Prasetyo, I. D. A., \& Darmayanti, N. P. A. (2018). Pengaruh Risiko Kredit, Likuiditas, Kecukupan Modal, dan Efisiensi Operasional Terhadap Profitabilitas pada PT BPD Bali. E-Jurnal Manajemen Universitas Udayana, 4(2), 2590-2617.

Putra, I. D. G. A.,\& Suardikha, I. M. S. (2016). Kemampuan Struktur Finansial, Pertumbuhan Nasabah, dan Loan to Deposit Ratio Sebagai Predikator Rentabilitas Lembaga Perkreditan Desa. E-Jurnal Akuntansi Universitas Udayana, 14(1), 253.

Raharjo, Pamuji Gesang. Hakim, Dedi Budiman. Manurung, Adler Hayman.,\& Maulana, T. N. A. (2014). The Determinant of Commercial Bank Interest Margin in Indonesia: An Analysis of Fixed Effect Panel Regression. International Journal of Economics and Financial Issues, 4(2), pp:2.

Riyadi, S. (2015). Banking Asset and Liability Management. Lembaga Penerbit Fakultas Ekonomi Universitas Indonesi.

Safariah, M. A. (2015). Pengaruh Risk Profile, Earnings, dan Capital Terhadap Pertumbuhan Laba Perbankan yang Terdaftar di Bursa Efek Indonesia (BEI). Universitas Negeri Yogyakarta.

Siamat, D. (2005). Manajemen Lembaga Keuangan. "Kebijakan Moneter dan Perbankan." Jakarta: Fakultas Ekonomi Universitas Indonesia, Edisi Kesatu. https:// doi.org/10.1515/ci.2005.27.6.25

Sugiyono. (2017). MetodePenelitian Kuantitatif, Kualitatif dan R\&D. Bandung: PT Alfabet. In Sugiyono. (2017). MetodePenelitian Kuantitatif, Kualitatif dan RED. Bandung: PT Alfabet. https:// doi.org/10.1017/CBO9781107415324.004

Syafi'i, M. F. R. (2016). Pengaruh Risiko Kredit, Risiko Pasar, Risiko Operasional, dan Risiko Likuiditas Terhadap Profitabilitas Perbankan (Studi Kasus pada Bank yang Terdaftar di Bursa Efek Indonesia Periode 2010-2014). Universitas Pasundan.

Vatansever, M., \& Hepsen, A. (2015). Determining Impacts on Non-Performing Loan Ratio in Turkey. Journal of Applied Finance and Banking.

Warrad, L. H., \& Nassar, M. (2017). Could Profitability, Activity and Use of Equity Finance Increasing DuPont Model of Return on Equity? Jordanian Case. International Review of Management and Marketing.

Wiagustini, N. L. P. (2014). Dasar-Dasar Manajemen Keuangan (Udayana Un).

Wulandari. (2018). Pengaruh Rasio CAMEL Terhadap Profitabilitas (ROA) Pada Perusahaan Perbankan yang Terdaftar di Bursa Efek Indonesia. Jurnal Manajemen Universitas Yogyakarta 1(1), 512-521. 